\begin{tabular}{|c|c|c|c|}
\hline $\begin{array}{c}\text { RESEARCH } \\
\text { ARTICLE }\end{array}$ & $\begin{array}{r}\text { ADVANCE RESEARCF } \\
\text { Volume } 8 \mid \text { Issue } 2 \mid \text { De }\end{array}$ & $\begin{array}{l}\text { OCIAL SCIENCE } \\
-2231-6418\end{array}$ & \\
\hline $0=$ & DOI: 10.15740/HAS/ARJSS/8.2/294-298 & Visit us : www.researchjournal.co.in & \\
\hline
\end{tabular}

\title{
Psycho-social climate of school as a correlate of moral values among school children
}

Manveer Kaur*, Seema Sharma and Tejpreet K. Kang

Department of Human Development and Family Studies, College of Home Science, Punjab Agricultural University, LUDHIANA (PUNJAB) INDIA

\section{ARTICLE INFO :

$\begin{array}{lll}\text { Received } & : & 18.09 .2017 \\ \text { Revised } & : & 23.10 .2017 \\ \text { Accepted } & : & 07.11 .2017\end{array}$

\section{KEY WORDS :}

Perceived psycho-social climate, Moral values, Locale differences, Gender differences

\section{HOW TO CITE THIS ARTICLE :}

Kaur, Manveer, Sharma, Seema and Kang, Tejpreet K. (2017). Psycho-social climate of school as a correlate of moral values among school children. Adv. Res. J. Soc. Sci., 8 (2) : 294-298, DOI: 10.15740/HAS/ARJSS/8.2/294-298.

*Author for correspondence

\begin{abstract}
The present study was undertaken to assess the correlation between perceived psychosocial climate of school and moral values among school children. The present study was conducted in Ludhiana district of Punjab. The respondents of the study were school going children (aged 10-12 years) randomly selected from Government High School and Senior Secondary Schools located in rural and urban areas of Ludhiana district. To assess the psycho-social climate of school of the selected respondents the School Environment Inventory (SEI) by K.S Mishra was used. For assessment of moral values among children Moral Value Scale (MVS) (Gupta and Sen, 1971) was used. It was observed that all the dimensions of perceived psycho-social climate of school were positively significantly correlated with total moral values but the dimension of rejection and control had negative correlation with moral values. The correlation between perceived psycho-social climate of school with moral values was observed to be statistically significant among rural and urban children as well as among boys and girls, in positive direction indicating that perceived psycho-social climate of school is a positive correlate of moral values among children.
\end{abstract}

